\title{
Science in India*
}

\section{Progress OF ZOOLOGY}

Zoology and its advancement in India were chosen by Prof. G. Matthai as the subject of his presidential address before the Section of Zoology. The address dealt with the progress of zoology since the foundation of the Indian Science Congress in 1914, and more particularly with advances made since 1921 .

Oceanographical investigation of the Indian Ocean has been conducted, since the first meeting of the Indian Science Congress, mainly by R.I.M.S. Investigator (until 1926) and the John Murray Expedition (1933-34), under the direction of Lieut.-Colonel Seymour Sewell. Previously the Sealark Expedition, under the leadership of Prof. J. Stanley Gardiner, had surveyed the western Indian Ocean south of the Maldives, more particularly the islands of the Chagos Archipelago and the Mascarene region (during 1905-6 and 1908-9). The work of the Sealark Expedition was mainly on problems relating to coral reefs and atolls and their biology, and was a continuation of a previous study of the Maldives and Laccadives. The R.I.M.S. Investigator concentrated its work in the Andaman Sea and the Bay of Bengal. The recent work of the John Murray Expedition was in the region of the Arabian Sea not covered by the Sealark Expedition. The study of the deep-sea biology of this region was assisted by physical, chemical, hydrographic and topographic investigations. The Survey of India collaborated with the John Murray Expedition in the cruise down the Maldives for making pendulum observations with the view of determining the nature of the foundations on which the Maldives and Isaccadives are situated.

The work of the R.I.M.S. Investigator has extended our knowledge in regard to variation in the air temperature over the open waters of the Indian seas, in the wind force, in the amount of rainfall and in the relationship between the temperature of the sea surface and that of the air. There is always a vertical circulation of the layers of water caused largely by differences in temperature and salinity. A reversal of seasons is noticeable in the Indian seas at a depth of about 100 fathoms, comparable to the phenomenon that takes place in the temperate seas.

The 'Murray Ridge' discovered by the John Murray Expedition appears to be ultimately connected with the Carlsberg Ridge. The latter ridge divides the western region of the Indian Ocean into north-eastern and south-western halves. 'King Fuad Bank' is probably a submerged atoll with a distinct rim about $40 \mathrm{ft}$. high and a level floor 130 fathoms deep.

Regarding the reefs of the Western Indian Ocean, Prof. J. Stanley Gardiner recently pointed out that the Mascarene Region differs from the Chagos Archipelago in regard to conditions of reef-growth, changes adverse to reef-growth taking place at a much higher rate than in the latter. The regression of coral reefs in the Mascarene region does not appear to be due to any biological reason such as sedentary organisms that cause destruction by boring into the reefs, since the activity of such organisms is decreased at the depths at which reefs of this region are situated, or by sediment, which cannot settle on

* Continued from page 297. the seaward sides of reefs and banks, or by precipitation of calcium carbonate (for such precipitation is not visible on coral polyps on the seaward sides), or by currents the action of which is less on the sides facing the sea, or by temperature, which at 50 fathoms is not lower than $61 \cdot 9^{\circ} \mathrm{F}$., or by any decrease in the amount of plankton that serve as food material to coral polyps, for it is not liable to much quantitative variation in the Indian Ocean; nor does the chemical composition of the surface water in the Indian seas show any appreciable difference. The comparative poverty of the deep sea fauna in the Chagos and Mascarene regions is perhaps due to the hardness of the sea floor and to the fact that the quantity of plankton which serves as food material to the larger organisms is less in the Indian seas than in the temperate regions. In spite of the "shallow and fierce conditions" of life on the reefs of these regions, it is interesting to observe that the animals do not exhibit any special structural features that may be regarded as adaptations to the peculiar environmental conditions.

The madreporarian corals collected by Prof. J. Stanley Gardiner in his several expeditions to the Indian Ocean, particularly of the astraeid corals, provided material for a comparative study, of the morphological organization of their hard and soft parts, with the view of determining, if possible, the limits of species and genera, most previous taxonomic studies on corals having been based on characters taken solely from the hard parts that are liable to considerable variation. The same material, along with others, formed the basis for a study of colonyformation in astraeid corals.

The Zoological Survey of India has been engaged mainly in faunistic investigation, more especially of the brackish water of the Chilka Lake and its island (Barkuda), the estuarine fauna of Goa, the fauna of the Mutlah River, of the Inle Lake, the Indian freshwater molluscs and their trematode parasites, the aquatic and terrestrial fauna of the Punjab Salt Range, the cave fauna of the Siju Cave in Assam. Particular attention has been paid to the study of the fishes of hill streams in various parts of India and their structural and other adaptations to this peculiar environment. Fisheries research, especially on Trochus, has been conducted in the Andamans.

The address ends with a brief account of the research work carried out in the various zoology departments in India.

\section{ENTOMOLOGY IN INDIA}

The past, present and future of entomology in India formed the subject of Mr. M. Afzal Husain's presidential address to the Section of Entomology.

Linnæus (1758) included in his "Systema Naturæ" twelve species of Indian insects, and thirty years later Fabricius (1792-98) included in his "Entomo. logia systematica" one thousand Indian species, collected mostly by the Christian missionaries. During the last hundred and fifty years insects have received much attention. The number of the existing species of insects in India cannot be less than 2.5 millions, but only one in sixty is known. The 
condition of Indian insect collections is also very unsatisfactory. It is distressing to find that most of the 'types' of Indian insects have gone out of the country. In the museums there is scarcely one 'type' for every hundred species described.

The Indian Museum laid the foundation of agricultural entomology in 1884 and the Imperial Institute of Agricultural Research at Pusa and the Agricultural Departments in the provinces and some Indian States have carried on the work. The Indian Central Cotton Committee, the Imperial Council of Agricultural Research, the Indian Tea Association and the Indian Lac Association have fostered the study of the insects of agricultural importance. Similarly, the small band of workers in forest entomology have achieved much success.

Ronald Ross and the workers who followed him made most valuable contributions to medical entomo. logy, which have been of utmost utility to humanity. The Indian Research Fund Association has financed much research on insects of medical importance. Veterinary entomology has been greatly ignored, and it is only lately that an entomologist has been appointed to study insect pests of domesticated animals. In education, entomology has long been the Cinderella among sciences. Even in agricultural colleges it is only within the last few years that entomological teaching has received some attention. In most medical and veterinary colleges, entomology has no place in the curricula.

India is equally behind in entomological literature. There is no literature on insects in any of the vernaculars of India. The "Fauna of British India" is not developing as fast as one would wish it to develop. There are few catalogues of insect groups.

According to Sir Thomas Holland, among the sciences of economic value entomology perhaps ranks first in importance to India. Sir Mirza Ismail has drawn a very gloomy picture of the conditions in India. More than one hundred million people suffer from malaria every year and more than one million succumb to its effects. "The debility, poverty and apathy caused by this disease are factors of magnitude in retarding the national, social and economic pro. gress of the country". Anopheles brought about the decay of the Greek and Roman civilizations, and is to-day one of the major obstacles to progress in India. According to Fletcher, the sugar-cane pests alone cause an annual loss of $300,000,000$ rupees. The hide industry of India suffers a yearly loss of 1.5 crores of rupees from one insect-ox warble fly. At a very modest computation, the annual loss caused to India by insects has been put at 200 crores of rupees, and a loss of more than a million and a half of human lives. It is a truism that insects have been responsible for more destruction of property and loss of life than that caused by all the wars, floods, earthquakes, fires and famines in human history, and the losses caused by them are on the increase. Advancing civilization is producing conditions most suitable for insect multiplication and spread.

The tribute of Rs. 200 crores which India pays to the demons Satpada is a heavy drain, which should not be permitted to continue. An effective defence against these enemies will reduce this enormous wastage, and India will have enough money for her national development. To effect this, an army of workers must be produced to study insect life in all its aspects, and an army well equipped with knowledge and machinery to fight these demons. The public must be made to appreciate the importance of insect study. Entomology must take its place in the schools and universities, agricultural, medical and veterinary colleges. Funds should be provided to develop pure and applied entomology. India has depended far too long on the generous assistance of foreign workers and institutions for the progress of Indian entomology, but the time has come when she must shoulder her own burden. In every province and every State, insect surveys should be conducted, museums for insect collections and insect study established, Indian universities should come forward to take their full share in entomological development. An Entomological Society of India and an entomological journal are also needed.

\section{Racial Composition of the Hindukush Tribes}

Dr. B. S. Guha in his presidential address to the Anthropological Section discussed the racial composition of the Hindukush tribes.

The region south of the Hindukush and Karakorum Mountains occupies a strategic position in the racial geography of India, for in these difficult, high mountainous valleys are still sheltered some of the remnants of the northern steppe folk who invaded India in the second millennium B.c.

Linguistically the tribes living in this area can be classified under two heads, namely, Dardic and Burushaski, with Kaffiri occupying an intermediate position between Iranian and Indian. Burushaski is unrelated to any known language; but Morgenstierne's investigations have shown the essentially Indian character of the Dardic and even the Kaffiri languages.

The earliest investigations on the somatic characters of these interesting tribes were those of Ujfalvy, followed by Stein, Dainelli and B. S. Guha, who, as a member of the scientific expedition sent by the Government of India, visited Kaffristan and Chitral in 1929 .

From a careful consideration of physical characters, it appears that the basic racial type in the entire region is a short, dark dolichocephalic strain with prominent long nose, often aquiline, which might be regarded as a variant of Eugen Fischer's Oriental race and the most characteristic type of the region.

Besides this principal type, there is the southern extension of a broad-headed race closely allied to what is known as the Dinaric race of eastern Europe. In its surongest form it is found among the Khos of the Chitral valley and the Burushos of Hunza Nagir, though it occurs throughout the Dardic tribes in varying degrees. The skin colour in this race is prevailingly of a rosy white tint, but the eyes are more often hazel and green, and the colour of the hair is brown.

The third main racial strain is a tall dolichocephalic type with long and straight nose. It forms a very important layer among the Kaffir and the upper stratum of the Burusho and the Dardic tribes. The distribution of the cephalic index in this type follows the same trend as found by Ariens Kappers in the races of the Aral Caspian regions and very similar to that which forms the dominant element in the northern European population, from whom its chief distinction lies in the integumentary colours. Whereas in Sweden the blond type represents 49 per cent of the population, among the Kaffirs it does not exceed 15 per cent. Blondness, as is well known, is due to a deficiency mutation which suppresses the appearance of pigment. It is certain that this 
deficiency mutation has occurred in this and at least in another, namely, the East-Baltic race, at some time or other. It is probable that the mutations for skin, hair and eye colours have taken place separately. In the Baltic tribes, the high rate of the deficiency mutation might probably account for the larger percentage of the blond as compared to the Hindukush tribes, among whom the activators are perhaps dominant over suppression, causing the general persistence of the more pigmented people.

Lastly, an intruding Mongoloid element must also be responsible for the yellowish tint in the skin colour and broad flat nose found among many individuals.

The proportions of these strains vary in different parts. The Dinaric and the Proto-Nordic elements are stronger in the western valleys, whereas the basic Oriental and the Mongoloid elements are more conspicuous in the eastern valleys of the Upper Indus.

\section{Breeding Investigations in the Sugar-Cane}

Hybridization in and with the genus Saccharum formed the topic of Rao Bahadur T. S. Venkatraman's presidential address to the Section of Agriculture. Hybridization in the sugar-cane at the Imperial Sugar-cane Station at Coimbatore represents the first attempt to improve the subtropical types of canes. This genetical work, which has been going on at the Station for more than twenty-five years, has involved six species of Saccharum and four genera. There appear to be two distinct groups of wild species of Saccharum, both of which are confined to south-east Asia. Some of the wild species show wide variations. For example, a survey of the Indian wild species, $S$. spontaneum, showed a variation in sugar content of the juice from 0.5 per cent to 17.0 per cent, the latter figure being higher than that of certain cultivated Indian canes.

The Indian canes belonging to the species $S$. barberi are cultivated in subtropical India, though some are found farther south. Certain Indian canes cannot be ascribed to the genus Saccharum, the most important being the Mungo group of Dr. Barber.

A wide range of forms is known to arise from sugar-cane seed. This is explained by the heterozygous nature of the parents and the fact that most sugar- canes in cultivation are polyploid; for example, S. offinarum is octoploid.

Very little in-breeding has taken place in the sugarcane, but much work has been done on inter-varietal, inter-specific and even inter-generic hybridization. Inter-varietal hybridization has been confined mostly to $S$. officinarum. At Coimbatore, economically important inter-specific hybrids have been obtained from S. officinarum $\times S$. spontaneum. In Australia and Hawaii, $S$. robustum is being used for producing hardier seedlings for tropical regions.

At Coimbatore, inter-generic hybridization has been carried out, using such genera as Sorghum and Bambusa. The Sorghum cross was introduced to produce a shorter life-cycle which in the sugar-cane is from twelve to even twenty-four months. Hybrids producing a crop in seven months have been produced, and these have had high quality juices. Growth vigour in these, however, has proved disappointing. Crossing with the bamboo (Bambusa) has been introduced in order to obtain greater vigour, but experimental work has not proceeded far enough yet to justify definite conclusions, from the economio point of view.

The previously mentioned inter-generic hybrids have shown some interesting phenomena with regard to the manner in which the characters are shown in the $F_{1}$ generation and transmitted in further back. crosses with either parent. In both the Sorghum and Bambusa hybrids with sugar-cane, the one fact that stands out prominently is the general dominance of Saccharum characters in the $F_{1}$ generation.

In the case of Saccharum $\times$ Sorghum hybrids, the general dominance of Saccharum characters was found to persist even after twice back-crossing the hybrids with their Sorghum parent. Certain of the Sorghum hybrids exhibited morphological characters not found in either parent. Most of these hybrids were infertile in their first generation. On further vegetative propagation, however, some of them are showing an increasing fertility in the sexual organs with the result that, whereas in the earlier years no seeds could be obtained from these, it has since been possible to raise seedlings in large numbers from some of them and also to back-cross them with the two parents.

[To be continued.]

\section{The Prehistoric People of Palestine*}

\section{By Sir Arthur Keith, F.R.S.}

\begin{abstract}
$\mathrm{T}$ HE fossil remains of the earliest inhabitants of Palestine were discovered in caves of Mount Carmel by an expedition led by Miss Dorothy Garrod, and financed by two societies - the British School of Archæology in Jerusalem and the American School of Prehistoric Research. The early Palestinians were quite unlike any people now living, but are of profound interest, because, if not our actual ancestors, they are certainly near akin to the human stock which in the course of time gave the world its Caucasian or white inhabitants. Hitherto our search for the fossil ancestor of the white man has been in

* Substance of a lecture given by Sir Arthur Keith at the Royal College of Surgeons on February 14.
\end{abstract}

vain. Everyone is familiar with the place held by Palestine in our conception of human life at the dawn of history; the excavations made at Mount Carmel by Miss Garrod are destined to give that small country in the East an equally important place in our picture of man's prehistoric world.

What the expedition found was this. Man began to inhabit the caves of Mount Carmel long before the onset of the last glaciation of Europe. One cave from an archæologist's point of view is the richest ever opened; it was filled with fossiliferous earth tramped down by the feet of prehistoric man, until an accumulation more than 80 feet in depth had been formed. From bottom to top the strata were 